\title{
Erythrocyte Immobilisation with Total Protein Extracted from Gnetum gnemon L. Seeds on Variety of Solid Media
}

\author{
Hery Haryanto ${ }^{1, *}$ Steffanie Nurliana ${ }^{1}$ Syariffuddin Syarifuddin ${ }^{1}$ \\ ${ }^{1}$ Department of Biology, Faculty of Mathematics and Natural Sciences, University of Bengkulu, Kandang Limun, \\ Bengkulu 38112, Indonesia \\ *Corresponding author. Email: heryharyanto@unib.ac.id
}

\begin{abstract}
The objective of this research was to determine the effectiveness of erythrocyte immobilisation with total protein extracted from gnetum seeds on a variety of solid media, i.e., filter papers, doff plastics, and nitrocellulose membranes. Old gnetum seeds were ground to make powders. The powders were homogenized in ml PBS buffer containing anti-protease PMSF in a cool room. The homogenate was centrifuged in order to separate supernatant from pellet. Solid media were punched with a perforator, so the results were discs of papers, plastics, and nitrocellulose membranes. The solid media perforated discs were then dipped in gnetum total protein supernatants. The dipped discs were air-dried for a while. Human erythrocytes of all ABO groups were washed three times and diluted to suspension of $20 \%(\mathrm{v} / \mathrm{v})$ in $\mathrm{NaCl} 0,9 \%(\mathrm{w} / \mathrm{v})$. A small drop of erythrocyte suspension was put in middle of each solid media disc, and its blood suspension was spread evenly. Next, the disc was observed under an USB digital microscope to see whether there was erythrocyte immobilisation on solid media coated with total proteins of gnetum seeds or not. All the erythrocytes from human ABO groups were bound effectively, from strongest to weakest,to paper filters, nitrocellulose membranes, and plastics. The future use of erythrocyte immobilisation on a variety of solid media coated with of gnetum total protein seed may be useful for diagnosing diseases related patological erythrocytes with a specific marker.
\end{abstract}

Keywords: total protein, Gnetum gnemon, erythrocytes, immobilisation, filter paper, nitrocellulose, plastic.

\section{INTRODUCTION}

Gnetum gnemon L. (Indonesian name: melinjo, belinjo, bago, tangkil) is a member of Gnetaceae and native to Indonesia. The plants are cultivated by mostly Sumatra dan Javanese farmers for seed production. The old seeds are made for gnetum cracker (Indonesian = emping melinjo). Meanwhile young seeds and young leaves are consumed as vegetable in Indonesian cuisine [1]. Gnetum fruits have 3 layers of covering, the outer covering is sarcotesta that has green colour in young fruits, yellow in middle young, and red colour in old fruits. Second layer is schlerotesta that is hard layer, and inner layer is thin endotesta.

The seeds contain $9-11 \%$ protein, $16.4 \%$ fat, $58 \%$ starch, stylbenoid, phenol/flavonoids, and resveratrol/poly-phenols [2]. Meanwhile flour from the dry seeds contain crude protein 19\% [3]. The protein may be used as an antioxidant because of their health benefit effects [4].

Crude protein extracts of the seeds can agglutinate erythrocytes of all human blood groups [5]. This suggests that gnetum seed protein contains lectins. Lectins that previously is wellknown as a phytohaemoagglutin binds reversibly to glycoconjugate molecules [6]. ABO blood groups are based on variety of monosacharide residue of glucoconjugate called antigen molecules [7]. Due to cross link with antigen molecules, lectins can aglutinate erythrocytes to form clumping cells. This raises the idea of whether the total protein extracts of gnetum seeds can be used for adhesion/immobilisation of erythrocytes in avariety 
of solid media, such as nitrocellulose membranes, filter papers, and plastics. The purpose of this research is to immobilize of erythrocytes from all blood groups on nitrocellulose membranes, filter papers, and plastics.

\section{MATERIALS AND METHODS}

\subsection{Materials}

Gnetum gnemon L. fruits were obtained from a farmer in Enggano Island about 12 hours sail by a ferry at Western part of Bengkulu Province. Gnetum fruits used in research were old fruits characterised by yellowish red sarcotesta.

\subsection{Methods}

\subsubsection{Preparation of Gnetum Powder}

Old gnetum fruits were peeled their red sarcotesta, then the seeds were dried under the sun for several days to dry. Schlerotesta was broken, and the epidermis covering the seeds were removed.The embryo and food reserves were ground to make powder as fine as possible.

\subsubsection{Total Protein Extraction and Fractionation}

Forty grams of the powder were homogenized in $\mathrm{ml}$ PBS buffer containing 3,2 $\mathrm{mM} \mathrm{Na}_{2} \mathrm{HPO}_{4}, 0,5 \mathrm{mM}$ $\mathrm{KH}_{2} \mathrm{PO}_{4}, 1,3 \mathrm{mM} \mathrm{KCl}, 135 \mathrm{mM} \mathrm{NaCl}, 1,5 \%$ (w/v) PVP (polyvinyl-pyrrolidine), $1 \mathrm{mM}$ PMSF (parametil sulfonil flouride), $1 \% \quad(\mathrm{v} / \mathrm{v})$ 2-Mercaptoethanol (Haryanto \& Kamilah, 2017). Homogenazation was carried out by using a magnetic stirring machine in a cool room overnight. Homogenate was centrifuged $4500 \mathrm{rpm}$ for 15 minutes in order to separate supernatant and pellet. The supernatant was added with $10 \%(\mathrm{w} / \mathrm{v})\left(\mathrm{NH}_{4}\right)_{2} \mathrm{SO}_{4}$ to presipitate protein, stirred overnight, and centrifuged at $12000 \mathrm{rpm}$ for 30 minutes. Pellets were presipitated protein, and diluted in $75 \mathrm{ml}$ of $0,9 \%(\mathrm{w} / \mathrm{v}) \mathrm{NaCl}$ to make a solution.

\subsubsection{Preparation of erythrocyte suspension}

Bloods were take out from antecubital fossa vein of donors. Bloods were put in EDTA vacuum blood tubes. The tubes were centrifuged at $4500 \mathrm{rpm}$ for 5 minutes to separare plasma from red blood cells. The plasma was removed, and red blood cells were washed three times with $0,9 \%(\mathrm{w} / \mathrm{v}) \mathrm{NaCl}$. Red blood cells were diluted to $20 \%(\mathrm{v} / \mathrm{v})$, one fifth volume of red blood cells was added with four fifth volume of $0,9 \%(\mathrm{w} / \mathrm{v}) \mathrm{NaCl}$.

\subsubsection{Preparation of Solid Media}

Solid media that were used in this research were Whatmann 42 filter paper, plastic sheet for inkjet printer, and 0.45 nitrocellulose membrane. The solid media were punched with a perforator, so the results were discs with diameter about 3,4 $\mathrm{mm}$. The discs were put in a petri dish separately according the type of solid media, then the discs were washed with alcohol 70\%, and were air-dried. The dry discs were stored in a desicator until to be used.

\subsubsection{Immobilisation of Erythrocytes}

The solid media perforated discs were then dipped in Gnetum total seed extract supernatants. The dipped discs were air-dried for a while. A small drop of erythrocyte suspension $20 \%(\mathrm{v} / \mathrm{v})$ was put in middle of each solid media disc, and its blood suspension was spread evenly. Next, the disc was observed under a USB digital microscope to see whether there was erythrocyte immobilisation on solid media polished with total proteins of Gnetum seeds or not.

\section{RESULT AND DISCUSSION}

In this research both positive and negative control were used for detection erythocyte immbilisation on solid media. The positive control was by using poly L-lysane coated slide glasses which were routinely used in cell culture for enhanced cell attachment and adhesion. A drop of erythrocyte suspension on the side of poly L-lysine coated slide glass showed that there were erythrocytes bound to the surface in evenly distributed cells, but they did not agglutinate.

The negative control which used common glass slide did not showed agglutinated erythrocytes. Both positive and negative control were observed under a light microscope, because it was transparent solid media. For solid media that were not transparent, observation erythrocyte immobilisation by using an USB digital microscope.

All nontransparent solid media showed erythrocytes bound to the surface of media, even after total protein of gnetum seeds which had been coated to their surface, there were much more agglutinated erythrocytes (Figure 1). This is indicated by clumped cells forming aggregation. All solid media coated with total protein of gnetum seeds showed that erythrocytes were bound to gnetum seed protein behaving as protein lectins. These protein coated on the surface of solid media bound to molecule antigen of the surface of erythrocytes. 
Table 1. Effectiveness of erythrocyte immobilisation on a variety of solid media

\begin{tabular}{|c|c|c|c|c|c|}
\hline \multirow[t]{2}{*}{ Type of solid media } & \multicolumn{4}{|c|}{ Blood group } & \multirow[t]{2}{*}{ Remarks } \\
\hline & $\mathbf{A}$ & $\mathbf{B}$ & $\mathbf{A B}$ & $\mathbf{O}$ & \\
\hline Filter paper & $\sqrt{ }$ & $\sqrt{ }$ & $\sqrt{ }$ & $\sqrt{ }$ & No agglutination \\
\hline Filter paper + gnetum protein & $\sqrt{ } \sqrt{ } \sqrt{ }$ & $\sqrt{ } \sqrt{ } \sqrt{ }$ & $\sqrt{ } \sqrt{ } \sqrt{ }$ & $\sqrt{ } \sqrt{ } \sqrt{ }$ & agglutination \\
\hline Plastic doff & $\sqrt{ }$ & $\sqrt{ }$ & $\sqrt{ }$ & $\sqrt{ }$ & No agglutination \\
\hline Plastic doff + gnetum protein & $\sqrt{ } \sqrt{ }$ & $\sqrt{ } \sqrt{ }$ & $\sqrt{ } \sqrt{ }$ & $\sqrt{ } \sqrt{ }$ & agglutination \\
\hline Nitrocellulose membrane & $\sqrt{ }$ & $\sqrt{ }$ & $\sqrt{ }$ & $\sqrt{ }$ & No agglutination \\
\hline Nitrocellulose + gnetum protein & $\sqrt{ } \sqrt{ } \sqrt{ }$ & $\sqrt{ } \sqrt{ } \sqrt{ }$ & $\sqrt{ } \sqrt{ }$ & $\sqrt{ } \sqrt{ } \sqrt{ }$ & agglutination \\
\hline PolyL-lysine coated slide glass & $\sqrt{ }$ & $\sqrt{ }$ & $\sqrt{ }$ & $\sqrt{ }$ & No agglutination/+ control \\
\hline Slide glass & - & - & - & - & No agglutination/- control \\
\hline
\end{tabular}

\section{Types of \\ Solid \\ Media}

Blood Group

A

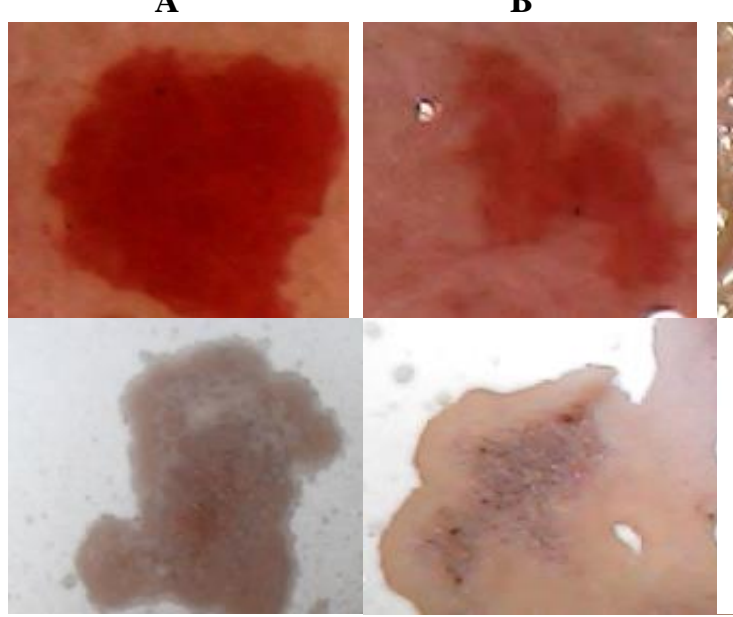

Filter

paper

Nitrocellul

ose
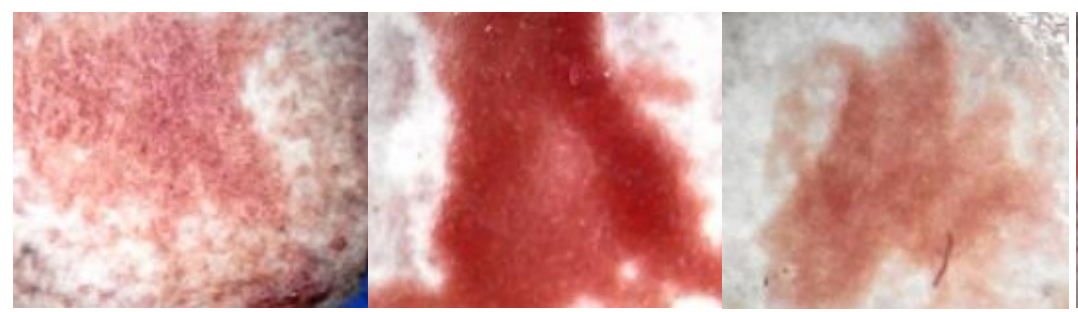

$\mathbf{O}$
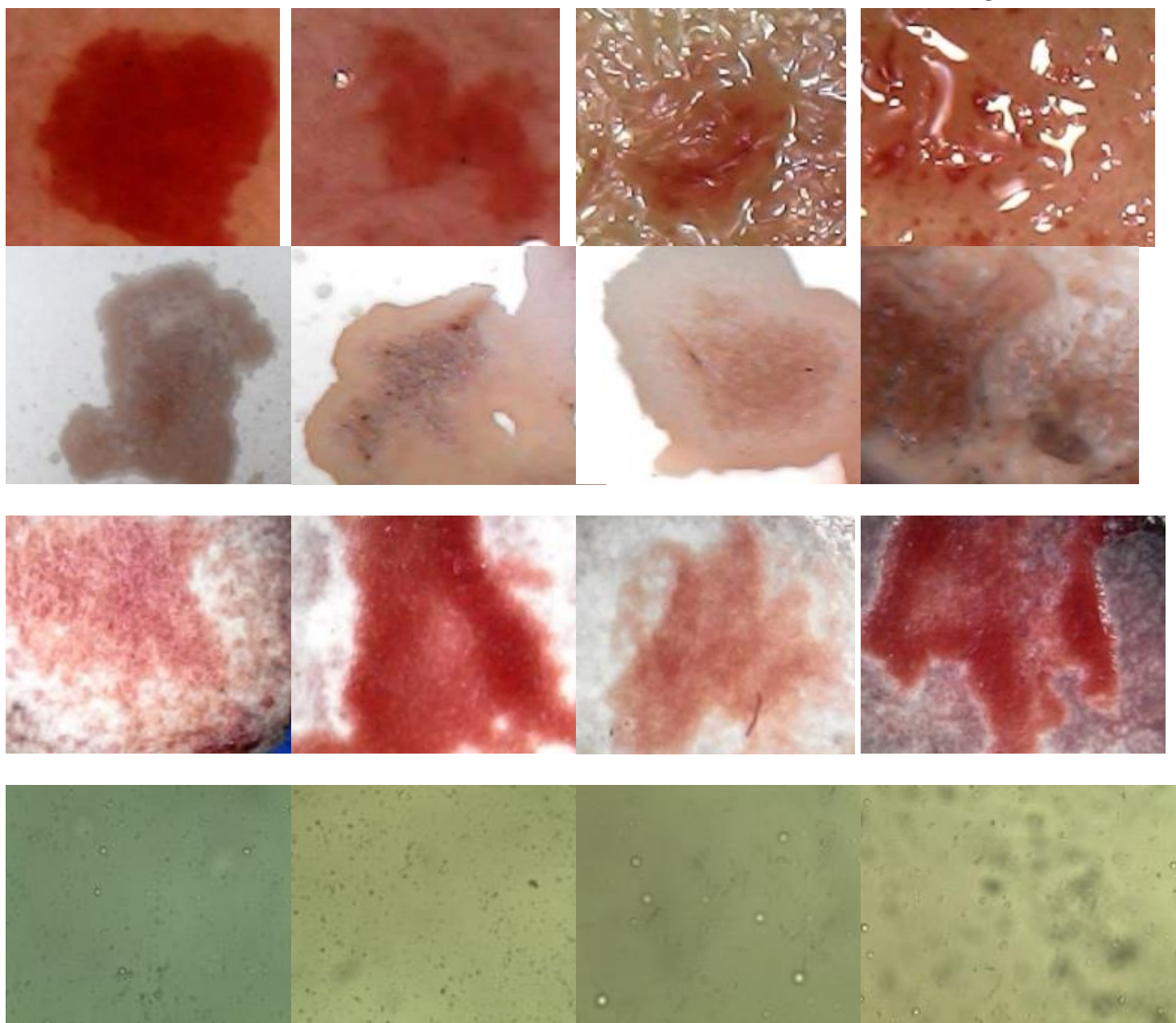

Poly L-

lysine

coated

glass

Figure 1. Photomicrographs of erythrocyte immobilisation on the surface of nontransparent solid media observed under an USB digital microscope, poly L-lysine coatedtransparent slide observed under a light microscope. 
The binding of erythrocytes and gnetum total protein due to cross link between blood group antigen molecules on the surface and proteins behaving as lectins. The lectins were as connecting molecules [8].

\section{CONCLUSION}

Human erythrocytes were bound effectively, from strongest to weakest to paper filters, nitrocellulose membranes, and plastics.

\section{ACKNOWLEDGMENTS}

This research was supported financially by Faculty of Mathematics and Natural Sciences, University of Bengkulu, contract No. 2051/UN30.12/HK/2020.

\section{REFERENCES}

[1] V.B. Hoe, K.H. Siong, The nutritional value of indigenous fruits and vegetables in Sarawak, Asia Pacific Journal of Clinical Nutrition 8(1) (1999) 24-31. DOI: 10.1046/j.14406047.1999.00046.x.

[2] T. Tatefuji, M. Yanagihara, S. Fukushima, K. Hashimoto, Safety assessment of Melinjo (Gnetum Gnemon L.) seed extract: acute and subchronic toxicity studies, Food and Chemical Toxicology 67 (2014) 230-35.

[3] Siswoyo, T. Agus, E. Mardiana, K.O. Lee, K. Hoshokawa, Isolation and characterization of antioxidant protein fractions from Melinjo (Gnetum Gnemon) seeds, Journal of Agricultural and Food Chemistry 59 (2011) 5648-5656. DOI: dx.doi.org/10.1021/jf2000647.

[4] Siswoyo, T. Agus, Bioactive proteins and peptides as potential components of nutraceuticals from Melinjo seed (Gnetum gnemon), Agricultural Research 16(1) (2018) 3.

[5] H. Haryanto, S. N. Kamilah, Studi mikroskopik penggumpalan eritrosit manusia dengan ekstrak protein kasar melinjo dari Pulau Enggano, Laporan Penelitian Pembinaan, LPPM Universitas Bengkulu, 2018. [In Bahasa Indonesia]

[6] K. Sano, H. Ogawa, Hemagglutination (inhibition) assay, in lectins: methods and protocols - methods in molecular biology, New York, Springer Science+Business Media, 1200 (2014) 47-51

[7] O. Baskurt, B. Neu, H. J. Meiselman, Red blood cell aggregation, CRC Press, 2012.

[8] A.F.S. Santos, T. Napoleao, R.F. Bezerra, E.V.M. M.Carvalho, P.M.G. Paiva, C.B B. Coelho, Strategies to obtain lectins from distinct sources, In Advances in Medicine and Biology, Nova Science Publishers Inc., 63 (2014) 34-60. 